\title{
PERSPEKTIF TEORI SENSE OF SERENITY PADA HISTORIC URBAN LANDSCAPE KAWASAN PASAR LAMA TANGERANG
}

\author{
Sarwosri Moertiningsih ${ }^{*}$, Dedes Nur Gandarum² \\ ${ }^{1}$ Mahasiswa Magister Arsitektur, Fakultas Teknik Sipil dan Perencanaan, \\ Universitas Trisakti, Jl. Kyai Tapa No. 1, Jakarta Barat, 11440 \\ ${ }^{2}$ Dosen Magister Arsitektur, Fakultas Teknik Sipil dan Perencanaan, \\ Universitas Trisakti, Jl. Kyai Tapa No. 1, Jakarta Barat, 11440 \\ *sarwosri.moer@gmail.com
}

\begin{abstract}
ABSTRAK
Sense of Serenity pada Historic Urban Landscape merupakan salah satu aspek penilaian pada Spirit of Place yang muncul sebagai obyek penting dalam konservasi kota secara holistik (Silva, 2015; Rifaioglu dan Guchan, 2013). Sense of Serenity pada sebuah kawasan konservasi digambarkan oleh Silva (2008 \& 2015) memiliki cirinya masing-masing. Sebagai contoh pada penelitiannya di Kandy dan di Bhaktapur, Sense of Serenity terbentuk oleh seting fisik, aktifitas dan pemaknaan yang berbeda di setap tempat memberikan keunikkan tersendiri. Seperti halnya di kawasan Pasar Lama Tangerang, yang memiliki Sense of Serenity yang unik. Lynch (1960) mengemukakan bahwa pemetaan kognitif manusia merupakan salah satu komponen yang menghasilkan keragaman Sense of Place.
\end{abstract}

Kata kunci: Sense of Serenity, Sense of Place, Historic Urban Landscape, kota, konservasi, Pasar Lama Tangerang.

\begin{abstract}
The Sense of Serenity in the Historic Urban Landscape is one aspect of the evaluation of the Spirit of Place that appears as an important object in holistic city conservation (Silva, 2015; Rifaioglu and Guchan, 2013). Sense of Serenity in a conservation area described by Silva (2008 \& 2015) has its own characteristics. For example in his research in Kandy and in Bhaktapur, Sense of Serenity is formed by different physical settings, activities and meanings in each place give their own uniqueness. As is the case in the Tangerang Old Market area, which has a unique Sense of Serenity. Lynch (1960) suggested that human cognitive mapping is one of the components that produce the diversity of Sense of Place.
\end{abstract}

Keywords: Sense of Serenity, Sense of Place, Historic Urban Landscape, urban, conservation, Pasar Lama Tangerang.

\section{PENDAHULUAN}

Konsep Lansekap Kota Bersejarah (Historic Urban Landscape) saat ini muncul sebagai konsep konservasi yang lebih dinamis untuk menyelesaikan permasalahan kawasan kota bersejarah. Kawasan bersejarah pada perkotaan sendiri, dapat memberikan imbal yang lebih tinggi terhadap kota tersebut, apabila memiliki makna 
yang mendalam yang dianalisis dan dipertahankan sebagai ungkapan nilai dan Spirit of Place seperti yang diungkapkan oleh O’Donnell (2008). Identifikasi Spirit of Place pada konsep lansekap kota bersejarah, dilakukan melalui Sense of Place, yang dibagi menjadi 4 dimensi inti dan dimensi resiko (Silva, 2008). Salah satu dimensi inti yang dikemukakan oleh Silva (2008) adalah Sense of Serenity.

Pada kawasan lansekap kota bersejarah, perspektif mengenai Sense of Serenity yang diungkapkan oleh Silva (2008 \& 2015) adalah, bahwa pada sebuah kawasan bersejarah yang memiliki karakter tempat unik, Sense of Serenity dapat timbul karena adanya faktor kesakralan atau ketenangan secara fisik dan kegiatannya yang kurang memiliki karakter umum kota, sehingga memunculkan pemaknaan Sense of Serenity secara kolektif. Sementara kota sendiri digambarkan oleh Kaplan (1984) memiliki karakter umum yang berlawanan dengan Sense of Serenity yang dikemukakan oleh Silva (2008 \& 2015). Pertanyaan yang kemudian muncul adalah apakah kualitas pengalaman yang menjadi dominasi pertimbangan dalam identifikasi Sense of Serenity dalam Historic Urban Landscape? Mengingat Sense of Serenity sebuah kawasan bersejarah dibentuk oleh seting fisik, kegiatan dan pemaknaannya yang menghasilkan kualitas pengalaman dari karakter tempat yang unik. Atau Sense of Serenity pada perkotaan memiliki pemaknaan lain yang berbeda dengan konteks serenity pada umumnya?

Kawasan Pasar Lama Tangerang merupakan salah satu tempat yang sudah masuk dalam daftar Kota Pusaka.
Melalui pendekatan konsep HUL, sebagai kawasan bersejarah, keunikan apa yang muncul di Kawasan Pasar Lama Tangerang dalam konteks Sense of Serenity?

\section{TEORI SERENITY DAN HISTORIC URBAN LANDSCAPE}

\section{Teori Serenity}

Kay T. Robert (1991) mengemukakan bahwa istilah Serenity pertama kalinya digunakan pada tahun 1599 untuk mendiskripsikan pernyataan suasana hati yang positif. Boyd-Wilson et al (2004) yang mengidentifikasi bahwa Serenity adalah pernyataan spiritual yang mengurangi stress, yang berhubungan dengan kedamaian secara personal. Serenity sendiri berasal dari bahasa latin serenus yang berarti tenang, damai (vocabulary.com). Dalam konteks ini, maka Serenity merupakan sebuah pernyataan suasana hati yang dimaknai sebagai ketenangan dan kedamaian secara personal.

Kemudian teori Serenity dalam konteks yang lebih luas dikemukakan oleh Pfau (1988) dalam Kay T. Robert (1991) yang menyatakan bahwa Serenity dapat digambarkan sebagai adanya kedamaian di hati dengan ketidakadaannya konflik mental yang membuat manusia bahagia dan nyaman dengan apa yang dimilikinya, dalam hal ini Pfau mengemukakan Serenity sebagai hal dimana manusia dapat menerima dan memahami semua keadaan. Sejalan dengan Pfau, masih dalam Kay T. Robert (1991), Jackson (1977) menyatakan bahwa Serenity adalah perasaan baik, dimana seseorang dapat beradaptasi dengan lingkungan sekitarnya. Artinya, Serenity dalam konteks yang lebih luas, diterjemahkan 
sebagai rasa yang timbul dari faktor internal seseorang karena adanya interaksi seseorang secara personal dengan lingkungannya, dan menghasilkan adaptasi positif.

Pada kawasan bersejarah, Ibrahim Abdallah (2012) mengemukakan bahwa pesona lingkungan bersejarah dari lansekap perkotaan salah satunya distimulasi oleh suasana hati, dimana di tempat yang memiliki karakter unik, mampu memicu timbulnya perasaan tenang (Nik Mastura et al, 2013). Lebih detail Lynch (1960) menyebutkan bahwa pemetaan kognitif merupakan salah satu komponen yang menghasilkan keragaman rasa antara manusia secara personal, pengalaman mereka, dan latar belakang yang menterjemahkan karakter seting fisik yang mempengaruhi keberadaan Sense of Place. Teori-teori tersebut menyebutkan bahwa identifikasi Serenity berasal dari faktor inter-personal, dimana faktor eksternal berperan sebagai pemicu timbulnya Serenity.

James Tabb (2016) mengemukakan ada 12 (dua belas) karakteristik Serene Environment yang dapat diberlakukan di setiap tempat, yaitu :

\section{Safe and untroubled;}

Tempat tersebut harus memiliki kepastian akan ketenangan, mampu mengurangi tingkat stress, tidak keostik, nyaman, tidak mengancam dan aman dari bahaya;

2. Authentic;

Memiliki keaslian dengan fitur-fitur penting, kejujuran, inegritas dan ekspresi yang nyata;

3. Coherent and Identifiable;
Memiliki atmosfir ketenangan yang menyehatkan, suasana kedamaian, tidak tersentuh oleh gangguan luar, bersih dan jelas;

\section{Human scale;}

Dalam skala pengukuran manusia secara fisik;

\section{Harmonious and balance;}

Memiliki keseimbangan yag memungkinkan untuk melakukan hal-hal yang baik secara optimal;

6. Connectedness with nature;

Memiliki keseimbangan dengan alam, yang mampu membangun hubungan positif dengan semua makhluk hidup, dan memiliki vitalitas;

\section{Mysterious and fascinating;}

Memiliki keindahan yang misterius dan kerahasiaan;

8. Enhanced perception and experience of sense;

Memiliki sensitifitas terhadap suara, dapat melihat seluas-luasnya dengan jelas, sensitif terhadap berbagai aroma, material, sejalan dengan kewaspadaan;

\section{Increase presence;}

Memiliki pergerakkan yang lambat, keterpusatan, menghargai dan menghormati kesejahteraan;

10. Transforming bealing;

Dapat mengurangi kepadatan secara temporal dan mengurangi stress;

11. Existence of grace and beauty;

Memiliki material yang berkualitas, elegan, dan ilusi bentuk;

12. Possesing the Spirit of Place;

Memiliki kekuatan hakiki, pesona, kualitas tempat yang menyenangkan dan sesuatu yang lain.

\section{Historic Urban Landscape}

Konsep awal dari Historic Urban Landscape adalah pengendalian pembangunan pada bangunan bersejarah dan sekitarnya atau pada kawasan kota bersejarah yang 
diketahui memiliki outstanding universal value (Martini, 2013), sehingga tidak kehilangan signifikansi kualitas kesejarahannya.

Kota dengan segala permasalahan mulai dari urbanisasi, perubahan iklim, kerusakan lingkungan hingga pergeseran budaya, merupakan sebuah monument dinamis yang berkembang secara cepat dan berkelanjutan. Pertumbuhan kota yang begitu cepat, seringkali mengubah inti dari banyak perkotaan yang bersejarah. Proses global memiliki dampak mendalam terhadap nilai-nilai yang dikaitkan oleh masyarakat terhadap daerah perkotaan dan seting mereka, dan pada persepsi serta realitas penghuni dan pengguna (UNESCO, 2011). Secara sederhana dan jelas, Kaplan (1984) mengemukakan, bahwa kehidupan kota jarang digambarkan sebagai ketenangan, kota disebut sebagai tempat yang memiliki hidup yang bersemangat, penuh warna, ramai, tergesa-gesa, menekan dan bising. Kota juga merupakan gambaran kehidupan heterogen, dimana kultur kehidupan masyarakatnya memiliki keanekaragaman dari berbagai aspek kehidupan kesehariannya. Hal ini dapat menyebabkan rusaknya Sense of Place dan identitas baik masyarakat maupun tempatnya. Pada beberapa daerah perkotaan yang memiliki nilai kesejarahan, mengalami kehilangan fungsi, peran dan populasi tradisionalnya.

Kota dalam konteks HUL, menganggap keragaman budaya dan kreativitas sebagai aset utama bagi perkembangan manusia, sosial, dan ekonomi (UNESCO, 2011). Keseimbangan antara karakteristik dan nilai-nilai yang terkait dengan sejarah terhadap lingkungan tersebut, merupakan hal yang mampu mempertahankan kelangsungan kehidupan kawasan bersejarah pada perkotaan. Maka tradisi dan persepsi masyarakat setempat merupakan sebuah penilaian penting dalam penentuan kawasan HUL, dimana setiap kawasannya memiliki ciri dan identitas yang otentik dan signifikan, yang dapat dijadikan sebagai sebuah potensi pengembangan kawasan kota yang dikonservasi dengan konsep HUL.

\section{KAWASAN PASAR LAMA TANGERANG}

Kawasan Pasar Lama merupakan kawasan permukiman dan perdagangan, yang di dalamnya terdapat 3 (tiga) bangunan yang sudah masuk dalam daftar cagar budaya, yaitu Klenteng Boen Tek Bio, Masjid Jami’ Kalipasir dan Museum Benteng Heritage. Secara fisik, kawasan ini memiliki ciri kawasan Pecinan, yang dengan mudah dikenali. Beberapa bangunan rumah tinggal yang terdapat di kawasan tersebut masih memiliki ciri khas arsitektur Tiongkok, walaupun belum masuk dalam daftar cagar budaya. Salah satu bangunan yang sudah dicagarbudayakan, Klenteng Boen Tek Bio yang dibangun pada tahun 1684 ini, merupakan titik orientasi kehidupan masyarakat Tionghoa setempat dengan beberapa peristiwa sejarah yang mampu membangkitkan Sense of Place secara kolektif.

Saat ini kawasan Pasar Lama Tangerang menjadi salah satu tujuan wisata sejarah di Kota Tangerang. Selain aktivitas hunian dan perdagangan yang sudah berlangsung sejak lama adalah aktivitas hunian dan perdagangan yang dimulai pukul 5.00 pagi hingga 16.00 sore hari, kawasan ini masih memelihara tradisi budaya 
yang tetap dilaksanakan pada waktu-waktu tertentu. Aktivitas tradisi budaya ini tidak hanya melibatkan etnis tertentu, namun masyarakat setempat secara keseluruhan. Kawasan Pasar Lama ini terkenal dengan tradisi budaya yang berakulturasi, sejak lama.

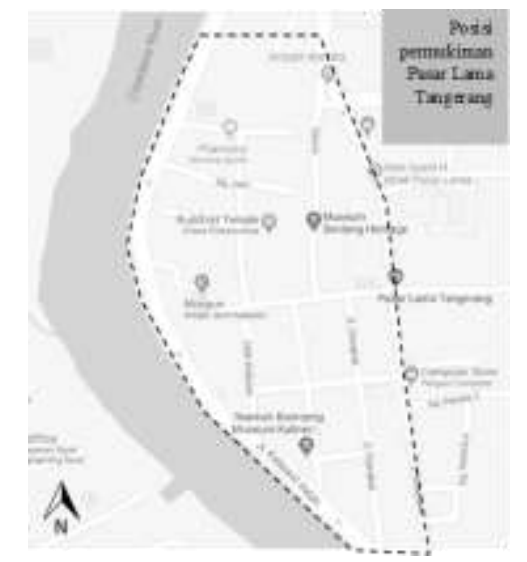

Gambar 1. Peta Kawasan Pasar Lama Tangerang

Sumber : diolah Peneliti,(2019)

\section{METODE PENELITIAN}

Penelitian ini menggunakan metode rasionalistik kualitatif, yang berangkat dari pendekatan holistik berupa grand concept mengenai Sense of Serenity yang dikemukakan oleh Montgomery (1998) dalam Carmona et al (2003), Silva (2008 \& 2015), dan oleh Tabb (2016) kemudian dijabarkan menjadi teori substantive pada konsep Historic Urban Landscape.
Penelitian ini dimulai dari kerangka teori yang dibangun dari buah pikiran para pakar diberbagai bidang yang terkait mengenai teori Serenity dan teori HUL, kemudian dikonstruksikan menjadi Sense of Serenity pada HUL. Sehingga kemudian pemaknaan dimunculkan dengan teori dasar Serenity yang dikemukakan oleh Jackson (1977), Kay T. Robert (1991), Pfau (1998) dan BoydWilson et al (2004).

\section{PERSPEKTIF TEORI SENSE OF SERENITY PADA HISTORIC URBAN LANDSCAPE KAWASAN PASAR LAMA TANGERANG}

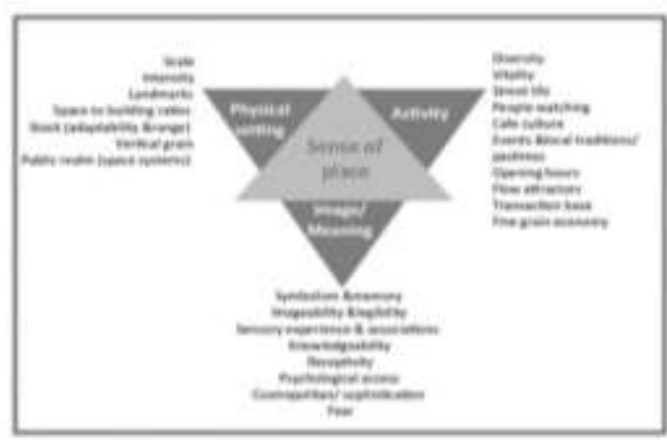

Gambar 2. Bagan Teori Sense of Place Sumber : Montgomery (1998) dalam Carmona et al (2003) 


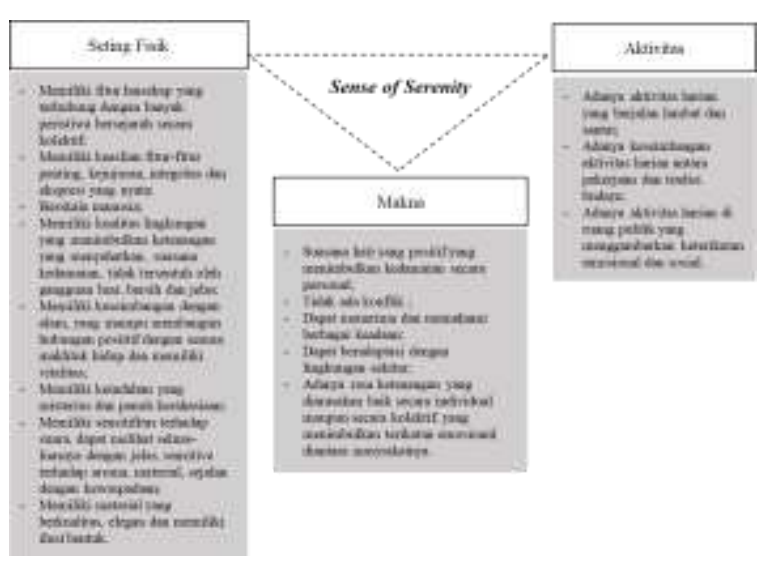

Gambar 3. Bagan Teori Sense of Serenity

Sumber : diolah oleh Peneliti,(2019)

Silva (2008 \& 2015) mengemukakan bahwa seting fisik dari Sense of Serenity salah satunya adalah memiliki fitur lansekap yang terhubung dengan banyak peristiwa bersejarah secara kolektif. Kawasan Pasar Lama Tangerang memiliki fitur lansekap yang berhubungan dengan banyak peristiwa sejarah. Tidak hanya 3 (tiga) bangunan yang telah masuk dalam daftar cagar budaya, namun hampir setiap elemen fisik memiliki sejarah terbangunnya kawasan ini yang diperkirakan sejak abad 14. Kawasan Pasar Lama Tangerang ini memiliki karakteristik fisik yang mencirikan bentuk hunian dan suasana lingkungannya, seperti yang diungkapkan oleh Antariksa (2016) bahwa masyarakat beretnis Tionghoa selalu memegang teguh prinsip-prinsip karakteristiknya, walaupun sudah mengalami akulturasi budaya.
Keaslian fitur-fitur di kawasan Pasar Lama Tangerang ini nyata dan signifikan. Tabb (2016) mengemukakan bahwa keaslian fitur-fitur penting, kejujuran, integritas dan ekspresi yang nyata, menjadi faktor penentu ketenangan sebuah lingkungan, dalam hal ini terkait dengan seting fisik yang mempengaruhi aktivitas dan pemaknaannya pada Sense of Serenity kawasan Pasar Lama Tangerang. Sejalan dengan konteks kota dalam HUL, bahwa sebuah kota dapat dikembangkan dengan konsep HUL apabila memiliki nilai otentik dan signifikan. Hal ini dapat diterjemahkan dalam seting fisik yang berupa fitur-fitur penting yang berperan penting dalam membentuk sebuah ketenangan, yang terkait dengan tradisi dan persepsi masyarakat setempat. Dalam skala pengukuran manusia secara fisik, Tabb (2016) menghubungkan skala ruang sebuah lingkungan mempengaruhi psikologis ketenangan pengguna. Namun Tabb tidak secara spesifik mengemukakan karakteristik skala yang mampu memberikan ketenangan. Dalam konteks kota secara umum, skala berkaitan dengan seting fisik yang mampu menciptakan kenyamanan ruang interksi bersama yang dapat dirasakan pengguna, sehingga memicu timbulnya perasaan tenang. Ashihara (1970) mengungkapkan apabila komposisi ruang melampaui $\mathrm{D} / \mathrm{H}=4$, interaksi bersama akan hilang. Sementara pada konteks HUL, aktivitas yang memunculkan nilai sosial, budaya, dan proses ekonomi, merupakan dimensi intangible yang terkait dengan keragaman dan identitas, akan muncul apabila ada ruang interaksi bersama. Pada kawasan Pasar Lama Tangerang, ruang yang tercipta intim dan cenderung dapat menyebabkan konflik ruang, terutama pada saat aktivitas perdagangan berlangsung. 
Adanya kemungkinan terjadinya konflik ruang pada saat aktivitas perdagangan berlangsung, justru menimbulkan ketenangan pada masyarakat setempat. Hal ini kontradiktif dengan pernyataan Tabb (2016) yang mengemukakan bahwa sebuah lingkungan yang memiliki Serene adalah tempat yang memiliki kepastian akan ketenangan, mampu mengurangi tingkat stress, tidak keostik, nyaman, tidak mengancam dan aman dari bahaya. Kawasan Pasar Lama Tangerang memiliki sifat kota yang tidak memiliki kepastian ketenangan, cenderung keostik, meningkatkan kadar stress dan tidak nyaman (Kaplan, 1984). Dalam konteks HUL, kota memiliki tradisi dan persepsi masyarakatnya sendiri yang merupakan sebuah penilaian penting dalam penentuan kawasan HUL. Persepsi sendiri merupakan faktor inter-personal, hal ini mengindikasikan bahwa kepastian akan sebuah ketenangan pada suatu tempat, bukan hanya timbul dari tempat itu sendiri, namun yang lebih penting adalah bagaimana tradisi dan persepsi masyarakatnya yang menganggap bahwa tempat tersebut dapat menimbulkan kenyamanan dan ketenangan dalam ukuran tradisi dan persepsi mereka. Akivitas perdagangan, yaitu pasar yang berada di tengah permukiman, memiliki kecenderungan kotor, berbau, berisik dan tidak teratur, seperti halnya yang terjadi di Kawasan Pasar Lama Tangerang. Namun kemudian tidak membuat kawasan ini tidak memiliki atmosfer ketenangan. Dijelaskan oleh Tabb (2016) bahwa Serene Environment memiliki atmosfir ketenangan yang menyehatkan, suasana kedamaian, tidak tersentuh oleh gangguan luar, bersih dan jelas. Pernyataan Tabb ini, dapat dikaitkan dengan seting fisik pada HUL yang mempengaruhi makna seseorang terhadap sebuah tempat dan peran komunitas pada masyarakatnya.
Seperti yang diungkapkan oleh Ibrahim Abdallah (2012) dalam Nik Matsura et al (2013) bahwa pesona lingkungan bersejarah dari lansekap perkotaan salah satunya distimulasi oleh suasana hati, dimana di tempat yang memiliki karakter unik, mampu memicu timbulnya perasaan tenang. Dalam konteks ini, Serene diterjemahkan sebagai rasa yang timbul dari faktor internal seseorang karena adanya interaksi seseorang secara personal dengan lingkungannya, yang kemudian diakumulasikan secara komunal dalam hal ini tidak hanya masyarakat setempat kawasan Pasar Lama Tangerang, namun termasuk para wisatawan yang menikmati atmosfer sebuah kawasan bersejarah, sehingga menghasilkan adaptasi positif pada lingkungan tersebut.

Kawasan Pasar Lama Tangerang berada di pusat kota Tangerang. Kawasan ini merupakan awal dari perkembangan kota Tangerang. Sebagaimana kota pada umumnya, permasalahan mulai dari perubahan iklim, urbanisasi, hingga pergeseran tradisi yang dapat mengakibatkan rusaknya keseimbangan alam lingkungan perkotaan (UNESCO, 2011) terjadi di sini. Tabb (2016) menekankan bahwa apabila ada keseimbangan dengan alam, maka ketenangan akan muncul. Hal ini selaras dengan pendapat Silva (2015), pada penelitiannya di Bhaktapur menemukan bahwa ketenangan pada masyarakat setempat didapat dari aktivitas keseharian yang seimbang, disatu sisi mereka memikirkan pekerjaan namun tidak membuat mereka meninggalkan tradisi budaya dan kesehariannya. Dalam HUL, konteks ini terkait dengan tradisi pada masyarakat setempat yang terjaga keberadaannya. Keseimbangan antara karakteristik dan nilai-nilai yang terkait dengan sejarah terhadap sebuah lingkungan, 
merupakan hal yang mampu mempertahankan kelangsungan kehidupan kawasan bersejarah pada perkotaan. Pada konteks ini, masyarakat yang bermukim di kawasan Pasar Lama Tangerang, begitu memegang erat keyakinan dan tradisi budaya yang sudah lama melekat. Hal ini dimanifestasikan pada ritual-ritual seperti Fang Sheng, yaitu melepas binatang ke alam, sebagai satu wujud rasa syukur kepada Sang Pencipta.

Faktor keseimbangan lain yang dikemukakan oleh Tabb (2016), adalah bahwa sebuah kawasan dapat dikatakan Serene apabila Memiliki keseimbangan dengan alam, yang mampu membangun hubungan positif dengan semua makhluk hidup, dan memiliki vitalitas. Sementara kota seringkali dihadapi dengan permasalahan mulai dari perubahan iklim, urbanisasi, hingga pergeseran tradisi yang dapat mengakibatkan rusaknya keseimbangan alam lingkungan perkotaan (UNESCO, 2011). Namun apabila mengacu pada pendapat Antariksa (2004) yang mengemukakan bahwa vitalitas kota dilihat dari kelayakan huni, memiliki daya saing pertumbuhan dan stabilitas ekonomi lokal, keadilan sosial dan berwawasan budaya yang terintegrasi. Sisi lain, Silva (2015) mengatakan bahwa Sense of Serenity, tidak ada kaitannya dengan signifikansi fitur alami, namun faktor fitur alami bisa menjadi salah satu pertimbangan yang dapat menciptakan Serene, sehingga vitalitas kota dapat terjaga. Serene Environment bukan tergantung pada keseimbangan alam, namun lebih tergantung pada keunikan seting fisik yang dimiliki oleh sebuah kota, namun dalam konteks HUL, hubungan yang seimbang dan berkelanjutan antara lingkungan perkotaan dan alam harus tetap dijaga sehingga mampu menimbulkan ketenangan, yang kemudian mampu memicu terciptanya vitalitas sebuah kota.

Kawasan Pasar Lama Tangerang sebagai titik awal pusat perekonomian di Kota Tangerang, hingga kini tidak kehilangan vitalitasnya. Fungsi kawasan sebagai kawasan perdagangan, tetap berjalan selama beberapa abad. Aktivitas hunian dan perdagangan yang begitu dinamis, menggambarkan ciri sebuah kota yang digambarkan oleh Kaplan (1984) adalah ramai dan bising. Selain itu kota memiliki tingkat kepadatan penduduk yang relatif tinggi dengan aktivitas yang serba tergesa-gesa dan menekan. Hal ini bertolak belakang dengan Serene Environment yang diungkapkan Tabb (2016), yang menjelaskan bahwa salah satu karakteristik Serene environment adalah memiliki sensitivitas terhadap suara, dapat melihat seluas-luasnya dengan jelas, sensitif terhadap berbagai aroma, material, sejalan dengan kewaspadaan. Namun kemudian, WHO dalam Bell (2005) mengemukakan bahwa kebisingan adalah suarasuara yang tidak dikehendaki, dalam hal ini lebih bersifat subjektif. Sejalan dengan teori tersebut, Lynch (1960) menyebutkan bahwa pemetaan kognitif merupakan salah satu komponen yang menghasilkan keragaman rasa antara manusia secara personal, pengalaman mereka, dan latar belakang yang menterjemahkan karakter seting fisik yang mempengaruhi keberadaan Sense of Place. Hal ini mengindikasikan bahwa sesuangguhnya ketenangan dalam konteks kota yang menyangkut sensitivitas suara, pandangan, aroma, dan material merupakan hal yang bersifat subjektif. Artinya, 
dalam HUL, konteks ini tergantung dari masyarakat pengguna.

Kaplan (1984) bahwa kehidupan kota cenderung berjalan dengan cepat dan bising, serta memiliki keterpusatan. Namun dalam konteks HUL, setiap tempat memiliki karakter unik yang mampu memicu timbulnya ketenangan. Pfau (1988) da Jackson (1977) mengemukakan bahwa Serenity dalam konteks yang lebih luas, diterjemahkan sebagai rasa yang timbul dari faktor internal seseorang karena adanya interaksi seseorang secara personal dengan lingkungannya, dan menghasilkan adaptasi positif. Artinya, selama ada interaksi yang menghasilkan adaptasi positif, bahkan di kota sekalipun, Increse presence dapat dicapai.

\section{KESIMPULAN}

Berdasarkan pembahasan teori-teori tersebut diatas, maka dapat diambil kesimpulan bahwa identifikasi Sense of Serenity pada Historic Urban Landscape didominasi oleh persepsi yang melahirkan pemaknaan personal yang kemudian dimaknakan secara kolektif, karena menimbulkan keterikatan emosiona diantara masyarakatnya.

Kawasan Pasar Lama Tangerang sebagai kawasan dengan fungsi campuran, hunian dan perdagangan memiliki beberapa ciri karakteristik kota, namun disisi lain juga memiliki beberapa ciri Serene Environment. Hal ini berarti bahwa Sense of Srenity sebuah kawasan, harus diidentifikasi secara tersendiri, karena memiliki keunikkan yang berbeda. Seperti yang diungkapkan oleh Jackson (1977), Pfau (1988) dan IbrahimAbdallah (2012), bahwa Serenity dalam konteks yang lebih luas, diterjemahkan sebagai rasa yang timbul dari faktor internal seseorang karena adanya interaksi seseorang secara personal dengan lingkungannya, dan menghasilkan adaptasi positif. Pemaknaan tersebut diakumulasikan menjadi pemaknaan kolektif sehingga penilaian tersebut dapat diidentifikasi dalam penentuan kawasan HUL, dimana setiap kawasannya memiliki ciri dan identitas yang otentik dan signifikan, yang dapat dijadikan sebagai sebuah potensi pengembangan kawasan kota yang dikonservasi dengan konsep HUL.

\section{DAFTAR PUSTAKA}

Silva D. Kapila. (2015). The Spirit of Place of Bhaktapur, Nepal. International Journal of Heritage Studies, page $1-22$.

Http://dx.doi.org/10.1080/13527258.2015.10289 62.

Martini, Viviana.(2013). The Historic Urban Landscapeas a new approach to The Conservation of Historic Cities. University of Nova Gorica Graduate.

Silva D. Kapila. (2008). Rethinking the Spirit of Place : Conceptual Convolutions and Preservation Pragmatics. https://www.icomos.org/quebec2008/cd/toindex/77 _pdf/77-Xfi8-72.pdf

Tabb. Philip James. (2016). Serene Urbanism : A Biopbilic theory and Practice of Sustainable Placemaking. Taylor \& Francis.

Boyd-Wilson, B.M. McClure J. \& Walkey. F.H. (2004) Serenity : Much More Than Just Feeling Calm.

Kaplan. Rachel. (1984). Impact of Urban Nature : A Theoritical Analysis, Urban Ecology, Elsevier Science Publisher B.V. Amsterdam.

Nik Mastura Nik Muhammad, Masran Saruwono, Shahrul Yani Said, Wan Ahmad Halawah Wan 
Hariri. (2013) A Sense of Place within The Landscape in Cultural Settings. Procedia-Social and Behavior Sciences 105.

Ibrahim Abdallah Shinbira.(2012). Conservation of The

Urban Heritage to Conserve The Sense of Place, A Case Study Misurata City, Libya. American Transactions on engineering \& Applied Sciences.

Kay T. Robert, Ed.D., R.N.,C. Linda Fitzgerald, M.S.N,R.N. (1991). Serenity : Caring with Perspective. Scholarly Inquiry for Nursing Practice : An International Journal, Vol. 5, No.2 